\title{
Nursing Intervention on Knowledge and Skills of Self-Management of Diabetes among Patients Attending Medical Out-Patient Clinic in Two Tertiary Hospitals in Ondo State
}

\author{
Olapeju Oke Ajibade, RN, RM, BNSc, $P G D E^{1^{*}}$ and Rasidi Akinade Salawu, BSc (Nursing), RN, RM, \\ PHD, FPNP Adv.Mgt., FWACN ${ }^{2}$
}

${ }^{1}$ School of Nursing, Babcock University, llisan-Remo, Ogun State, Nigeria

${ }^{2}$ Professor of Adult Health Nursing, Babcock University, Ilisan-Remo, Ogun State, Nigeria

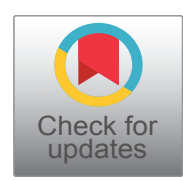

*Corresponding author: Olapeju Oke Ajibade, RN, RM, BNSC, PGDE, School of Nursing, Babcock University, Ilisan-Remo, Ogun State, Nigeria, Tel: +2348068576267

\begin{abstract}
Background: Diabetes mellitus is one of the global health burdens associated with inadequate management. Self-management is a pivot of diabetes management. It has been estimated that more than one-quarter of the admissions in Nigeria hospital is as a result of diabetes complication. The study assessed nursing intervention on knowledge and skill of self-management among diabetic patients attending medical out-patient clinics in two tertiary hospitals, Ondo State, Nigeria.

Materials and methods: This study adopted a two-group, pretest-posttest quasi-experimental research design. Total enumeration was adopted for the study, where all the diabetic patients at the facility per time were recruited. One hundred and twenty-one (121) respondents participated in the study; 40 in the control group and 81 respondents in the experimental group. A self-developed questionnaire and rating scale served as the instrument for data collection on demographic information, knowledge and skill of self-management of diabetes. Data were collected over five weeks in three phases of pre-intervention, intervention and post-intervention. An educational package served as tool for the nursing intervention to enhance their knowledge and skill on diabetes self-management.
\end{abstract}

Results: Mean knowledge score of participants on selfmanagement in the experimental group increased from $26.04 \pm 2.97$ to $30.57 \pm 0.64$ post-intervention. Mean score on skill of participants on self-management increased from $8.12 \pm 7.06$ to $20.77 \pm 4.82$ post-intervention. There was no significant increase in the mean knowledge score of the control group on knowledge and skill of self-management.
There were significant differences between the pre and post-intervention mean knowledge score of participants on self-management $(t=-13.72, p=0.000)$ and there was also significant difference in the pre and post intervention mean skill score of diabetes on diabetes self-management in the experimental group $(t=-17.01, p=0.000)$.

Conclusion: Conclusively, knowledge of self-management of diabetes was moderate while participants lacked knowledge on pertinent point. Also, skill of self monitoring of blood glucose and foot care was only fair among the participants. However, the educational package utilized in this study increased the knowledge and skill of participants on self-management of diabetes. Thus the study is hoped to enhance self-management and reduce complications among participants. It is recommended that nursing intervention programmes using a well-designed diabetes self-management educational package should be included in diabetic clinics at different level of health care settings.

\section{Keyword}

Knowledge, Skill, Self-management, Nursing intervention, Diabetes, Educational package
Abbreviations
DM: Diabetes Mellitus; DSME: Diabetes Self-Management Education; SMBG: Self-Monitoring of Blood Glucose; IDF: International Diabetes Federation; UNIMEDTH: University of Medical Science Teaching Hospital Ondo State; FMC: Federal Medical Center; WHO: World Health Organization 


\section{Introduction}

Diabetes mellitus result from inadequate blood glucose regulation and other major nutrients due to absence, insufficiency or resistance of insulin [1]. It is one of the largest global health emergencies of the $21^{\text {st }}$ century and among the top 10 causes of death. Every seven seconds, someone is estimated to die from diabetes or its complications, with $50 \%$ of those deaths (4 million in total per year) occurring under the age of 60 years [2]. On a global scale, diabetes hits particularly "middle-aged" people between 40 to 59 years of age which causes serious economic and social implications [3].

About 425 million people worldwide or $8.8 \%$ of adults 20-79 years are estimated to have diabetes with approximately $79 \%$ living in low and middle income countries. The number of people with diabetes may increase to 451 million if the age is expanded to $18-99$ years. There is prevalence of 7.7 million (2.6-17.4\%) of people with impaired glucose tolerance in 2017 and is likely to increase to 17.9 million (7.1-42.0\%) in 2045 globally [2].

According to World Health Organization [4], diabetes brings a variety of complications including cardiovascular and renal complications as well as diabetes foot ulcer and impotence. Indeed, diabetes brings a lot of burden on the patients and their family including the health system [5]. Consequently it imposes a large economic burden on the global health-care system and the wider global economy [6].

Persons with diabetes require continuing medical care and self-management health promotion education to prevent complications [5]. Significantly, self-management needs to continue over time if complications incidence will be reduced and lives of patients prolonged [7]. It is therefore imperative that individuals acquire the knowledge and skills necessary to effectively manage their condition on a day-to-day basis away from professional healthcare facilities, and thereby prevent or delay the development of complications [8].

Therefore diabetes self-management education (DSME) is the course of action of enhancing the knowledge and skills, capability needed for self-management of diabetes mellitus patients; it translates to the care which is required for initiating, maintaining and reinforcing essential coping skills as well as behaviours that are involved for self-management on daily basis [9]. Diabetes self-management is crucial to keep the disease under control; it includes carrying out activities such as healthy diet, regular physical activity, self-monitoring of blood glucose (SMBG), foot care and smoking cessation. The self-monitoring of blood glucose (SMBG) and foot care requires adequate skill that can be gotten from good knowledge of these activities $[10,11]$.

According to Jackson, Adibe, Okonta and Ukwe [7], for effective treatment of diabetes, patients must be fully involved in their management. A knowledgeable and skilful patient on self-management practices stands a positive chance to achieve and maintain glycaemic control and prevent complications. This implies that diabetes self-management education is essential and it involves an ongoing process of facilitating the knowledge, skill, and ability necessary for self-management practices.

In a review of self-management of diabetes in Africa, poor knowledge and skill was identified as one of the reasons affecting self-management. Poor knowledge could result from low literacy levels or poor understanding, which could arise from lack of education by health professionals [12].

Studies conducted on self-care practice and associated factors in western Africa revealed inadequate knowledge and skill as one of the possible reasons for poor self-management emphasizing that effective management of diabetes will be intricate without sufficient understanding of different domains of self-management of the condition $[10,13]$. Studies that had been carried out in Nigeria also revealed that there is poor knowledge and skill of self-management among diabetic patients and this occur in all domains, thus there is need for nursing intervention programme using educational package as a tool to reduce complications among these patients $[14,15]$. Hence, the need to carry out the study; nursing intervention on knowledge and skills of self-management of diabetes among patients.

\section{Objective}

The objective of the study was to assess nursing intervention on knowledge and skills of self-management of diabetes among patients attending medical out-patient clinics in two tertiary hospitals in Ondo State.

\section{Materials and Methods}

This study adopted 2 groups (experimental and control), quasi experimental research design employing purposive sampling method. Purposive sampling method was utilized because the two tertiary institutions in the states were best suited for the study. The experimental group received the intervention of interest while the control group got no intervention.

The study was conducted at University of Medical Sciences Teaching Hospital, Akure (UNIMEDTH) and Federal Medical Centre (FMC), Owo, Ondo State. Ethical clearances were obtained from the Ethics and Research Committees of both hospitals. The inclusion criteria were; patients that have been diagnosed of Type I and II diabetes who are attending the medical out-patient clinic of the selected tertiary health facilities. The exclusion criteria include Type I and II diabetic patients who were having complicated conditions like renal disease or hypertension or psychological conditions like depression. The participants in UNIMEDTH formed the experimental group with 81 participants while those in FMC formed the control group with 40 participants. 


\section{Data Collection}

A structured questionnaire and self developed rating scale were used to assess the level of knowledge and skill at the pre-intervention and post-intervention phase respectively. The questionnaire had two sections, namely; Section $A$ had 7 items that were used to collect socio-demographic data. Section B contained 31 items on knowledge of self-management. Self-developed rating scale was also used to evaluate respondents' skill on self monitoring of blood glucose and foot care. The rating scale which was an observational instrument was used to measure the above mentioned domain. It consisted of 12 responses that were rated between 0,1 and 2. Zero score for no skill at all, 1 score for some skill and 2 for good skill. Content and face validity of the instruments was ensured by experts in education and research. The reliability of the instruments was established through an internal consistency approach. This took place in a tertiary hospital in Ibadan, Oyo State Nigeria. Cronbach Alpha of the questionnaire after the reliability was 0.706 .

This study took place from May 18, 2020 to June 15, 2020. Participants were recruited using the inclusion criteria checklist. A total of $121 \mathrm{DM}$ patients were recruited, 81 and 40 formed the experimental and control groups respectively. Every detail of the study was explained to participants first, those that asked questions were given appropriate answers afterwards. Nur- sing intervention was given to the experimental group. The same procedures were repeated for the control group except the nursing intervention.

The maximum score for correct response for knowledge on self-management of diabetes was 31; the scores are categorized as follows: Below average knowledge is scores between 0 and 10 while average knowledge scores is between 11 and 20 and above average knowledge: between 21 and 31 . The maximum score for correct response for skill on self monitoring of blood glucose and foot care was 11; the scores were categorized as follows: No skill scores is between 0 and 4 , some skill scores is at 5 , and skilled score is between 6 and 11 .

The nursing intervention was an educational package on knowledge of self-management which was conducted via face to face teaching on diet plan, physical activity, self monitoring of blood glucose and foot care, while the skill section included demonstration of self monitoring of blood glucose and foot care to the participants in the experimental group for one month after the pre-intervention phase (Supplementary).

\section{Data Analysis}

Data obtained from the study were analyzed using the Statistical Package for Social Sciences (SPSS), version 25. Descriptive statistics such as frequency counts, percentages and mean scores were used to provide answers for research questions while inferential statistics

Table 1: Socio-Demographic Characteristics of the participants.

\begin{tabular}{|c|c|c|c|c|c|}
\hline \multirow[b]{2}{*}{ Variable } & \multirow[b]{2}{*}{ Characteristics } & \multicolumn{2}{|l|}{ Control } & \multicolumn{2}{|c|}{ Experimental } \\
\hline & & $\begin{array}{l}F \\
(n=40)\end{array}$ & $(\%)$ & $\begin{array}{l}F \\
(n=81)\end{array}$ & $(\%)$ \\
\hline Age in years & $\begin{array}{l}30-39 \text { years } \\
40-49 \text { years } \\
50-59 \text { years } \\
60 \text { years and above }\end{array}$ & $\begin{array}{l}2 \\
6 \\
14 \\
18\end{array}$ & $\begin{array}{l}5.0 \\
15.0 \\
35.0 \\
45.0\end{array}$ & $\begin{array}{l}1 \\
4 \\
20 \\
56\end{array}$ & $\begin{array}{l}1.2 \\
4.9 \\
24.7 \\
69.1\end{array}$ \\
\hline Religion & $\begin{array}{l}\text { Christianity } \\
\text { Islam }\end{array}$ & $\begin{array}{l}31 \\
9\end{array}$ & $\begin{array}{l}77.5 \\
22.5\end{array}$ & $\begin{array}{l}73 \\
8\end{array}$ & $\begin{array}{l}90.1 \\
9.9\end{array}$ \\
\hline Marital status & $\begin{array}{l}\text { Single } \\
\text { Married } \\
\text { Separated } \\
\text { Widowed }\end{array}$ & $\begin{array}{l}1 \\
36 \\
1 \\
2\end{array}$ & $\begin{array}{l}2.5 \\
90.0 \\
2.5 \\
5.0\end{array}$ & $\begin{array}{l}4 \\
65 \\
7 \\
5\end{array}$ & $\begin{array}{l}4.9 \\
80.2 \\
8.6 \\
6.2\end{array}$ \\
\hline Level of education & $\begin{array}{l}\text { No formal education } \\
\text { Primary } \\
\text { Secondary } \\
\text { Tertiary }\end{array}$ & $\begin{array}{l}3 \\
6 \\
8 \\
23\end{array}$ & $\begin{array}{l}7.5 \\
15.0 \\
20.0 \\
57.5\end{array}$ & $\begin{array}{l}11 \\
26 \\
16 \\
28\end{array}$ & $\begin{array}{l}13.6 \\
32.1 \\
19.8 \\
34.6\end{array}$ \\
\hline Occupation & $\begin{array}{l}\text { Employed } \\
\text { Unemployed } \\
\text { Retired }\end{array}$ & $\begin{array}{l}16 \\
11 \\
13\end{array}$ & $\begin{array}{l}40.0 \\
27.5 \\
32.5\end{array}$ & $\begin{array}{l}32 \\
17 \\
32\end{array}$ & $\begin{array}{l}39.5 \\
21.0 \\
39.5\end{array}$ \\
\hline Duration of Illness & $\begin{array}{l}0-5 \text { years } \\
6-10 \text { years } \\
11-15 \text { years } \\
16 \text { years and above }\end{array}$ & $\begin{array}{l}26 \\
9 \\
2 \\
3\end{array}$ & $\begin{array}{l}65.0 \\
22.5 \\
5.0 \\
7.5\end{array}$ & $\begin{array}{l}39 \\
26 \\
11 \\
5\end{array}$ & $\begin{array}{l}48.1 \\
32.1 \\
13.6 \\
6.2\end{array}$ \\
\hline
\end{tabular}


of student t-Test was used to provide answers to four hypotheses at 0.05 level of significance.

\section{Results}

Table 1 shows that about half of the respondents in both control and experimental groups were within the age 60 years and above signifying $45 \%$ and $69.1 \%$ respectively. A larger percentage of the respondents were Christians with $77.5 \%$ in the control and $90.1 \%$ in the experimental group. Majority of the respondents were married in both groups with $90 \%$ and $80.2 \%$ in the control and experimental groups respectively. Only about half of the participants $(57.5 \%)$ in the control and two-fi$\mathrm{fth}(34.6 \%)$ in experimental group had tertiary education. Majority of the respondents were unemployed with $77.5 \%$ and $71.1 \%$ in the control and experimental groups respectively. Only about two-fifth of the respondents in both control and experimental were employed; $40.0 \%$ and $39.5 \%$ respectively. A larger percentage of the respondents had the illness between $0-5$ years in both control and experimental group; $65 \%$ and $48.1 \%$ respectively.

Results from Table 2 show that 39 respondents in the control group had pre-intervention knowledge that is above average on self-management of diabetes representing $97.5 \%$ and, 77 participants (95.1\%) in the experimental group also with knowledge above average. Four (4) participants had average knowledge in the experimental group representing $4.9 \%$.

Post-intervention, above-average knowledge was 38 (95\%) for control group and $81(100 \%)$ for the experimental group. Only two respondents (5\%) had average knowledge in the control group. The pre and post-intervention mean scores for the control group were $25.81 \pm$ 2.58 and $25.50 \pm 2.52$ respectively. While for the experimental group, the pre and post-intervention mean scores were $26.04 \pm 2.97$ and $30.57 \pm 0.64$. The mean gain for the control group was -0.31 while that of the experimental group was 4.53. The maximum scores for pre and post-intervention for the control group was 30.15 and 31 for experimental. While the minimum pre-inter-

Table 2: Pre and post-intervention mean knowledge score of diabetic patients on self-management of diabetes among the control and experimental groups.

\begin{tabular}{|c|c|c|c|c|c|c|c|c|c|}
\hline \multirow{3}{*}{$\begin{array}{l}\text { Mean knowledge } \\
\text { score of patients on } \\
\text { self-management of } \\
\text { diabetes }\end{array}$} & \multirow{3}{*}{ Score range } & \multicolumn{4}{|c|}{ Control } & \multicolumn{4}{|c|}{ Experimental } \\
\hline & & \multicolumn{2}{|c|}{ Pre Intervention } & \multicolumn{2}{|c|}{ Post Intervention } & \multicolumn{2}{|c|}{ Pre Intervention } & \multicolumn{2}{|c|}{$\begin{array}{l}\text { Post- } \\
\text { Intervention }\end{array}$} \\
\hline & & $\mathbf{F}$ & $\%$ & $F$ & $\%$ & $\mathbf{F}$ & $\%$ & $\mathbf{F}$ & $\%$ \\
\hline Above average & $21-31$ & 39 & 97.5 & 38 & 95.0 & 77 & 95.1 & 81 & 100.0 \\
\hline Average & $11-20$ & 1 & 2.5 & 2 & 5.0 & 4 & 4.9 & 0 & 0.00 \\
\hline Below average & $0-10$ & 0 & 0 & 0 & 0 & 0 & 1.32 & 0 & 0.00 \\
\hline Total & & 40 & 100 & 40 & 100 & 81 & 100 & 81 & 100 \\
\hline Mean & & \multicolumn{2}{|c|}{$25.81 \pm 2.58$} & \multicolumn{2}{|c|}{$25.50 \pm 2.52$} & \multicolumn{2}{|c|}{$26.04 \pm 2.97$} & \multicolumn{2}{|c|}{$30.57 \pm 0.64$} \\
\hline Mean Gain & & \multicolumn{4}{|c|}{-0.31} & \multicolumn{4}{|c|}{4.53} \\
\hline Maximum & & \multirow{2}{*}{\multicolumn{2}{|c|}{$\begin{array}{l}30.15 \\
19.53\end{array}$}} & \multirow{2}{*}{\multicolumn{2}{|c|}{$\begin{array}{l}28.88 \\
19.11\end{array}$}} & \multirow{2}{*}{\multicolumn{2}{|c|}{$\begin{array}{l}31.00 \\
17.84\end{array}$}} & \multirow{2}{*}{\multicolumn{2}{|c|}{$\begin{array}{l}31.00 \\
28.03\end{array}$}} \\
\hline Minimum & & & & & & & & & \\
\hline Range & & \multicolumn{2}{|c|}{10.62} & \multicolumn{2}{|c|}{9.77} & \multicolumn{2}{|c|}{13.16} & \multicolumn{2}{|c|}{2.97} \\
\hline
\end{tabular}

Table 3: Pre and post-intervention mean skill score of diabetic patients on self-management of diabetes among the control and experimental groups.

\begin{tabular}{|c|c|c|c|c|c|c|c|c|c|}
\hline \multirow{3}{*}{$\begin{array}{l}\text { Mean skill score } \\
\text { of patients on self- } \\
\text { management of } \\
\text { diabetes }\end{array}$} & \multirow{3}{*}{ Score range } & \multicolumn{4}{|c|}{ Control } & \multicolumn{4}{|c|}{ Experimental } \\
\hline & & \multicolumn{2}{|c|}{ Pre Intervention } & \multicolumn{2}{|c|}{ Post Intervention } & \multicolumn{2}{|c|}{ Pre Intervention } & \multicolumn{2}{|c|}{ Post- Intervention } \\
\hline & & $\mathbf{F}$ & $\%$ & $\mathbf{F}$ & $\%$ & $\mathbf{F}$ & $\%$ & $\mathbf{F}$ & $\%$ \\
\hline Skilled & $6-11$ & 24 & 60 & 24 & 60 & 38 & 46.9 & 57 & 70.4 \\
\hline Some skill & 5 & 13 & 32.5 & 11 & 27.5 & 20 & 24.7 & 23 & 28.4 \\
\hline No skill & $0-4$ & 3 & 7.5 & 5 & 12.5 & 23 & 28.4 & 1 & 1.2 \\
\hline Total & & 40 & 100 & 40 & 100 & 81 & 100 & 81 & 100 \\
\hline Mean & & \multicolumn{2}{|c|}{$13.25 \pm 6.07$} & \multicolumn{2}{|c|}{$13.05 \pm 6.44$} & \multicolumn{2}{|c|}{$8.12 \pm 7.06$} & \multicolumn{2}{|c|}{$20.77 \pm 4.82$} \\
\hline Mean Gain & & \multicolumn{4}{|c|}{-0.20} & \multicolumn{4}{|c|}{12.65} \\
\hline Maximum & & \multirow{2}{*}{\multicolumn{2}{|c|}{$\begin{array}{l}27 \\
14\end{array}$}} & \multirow{2}{*}{\multicolumn{2}{|c|}{$\begin{array}{l}26 \\
14\end{array}$}} & \multirow{2}{*}{\multicolumn{2}{|c|}{$\begin{array}{l}24 \\
0\end{array}$}} & \multirow{2}{*}{\multicolumn{2}{|c|}{$\begin{array}{l}40 \\
7\end{array}$}} \\
\hline Minimum & & & & & & & & & \\
\hline Range & & \multicolumn{2}{|l|}{13} & \multicolumn{2}{|l|}{12} & \multicolumn{2}{|l|}{24} & \multicolumn{2}{|l|}{33} \\
\hline
\end{tabular}


vention score for the control group and experimental group were 19.53 and 17.84 respectively; and minimum post-intervention scores for both the control and experimental groups were 19.11 and 28.03 respectively. The ranges (pre and post-intervention) for control group were 10.62 and 9.77 respectively, while the ranges for the experimental group were also 13.16 and 2.97 respectively.

Results from Table 3 reveal that in the control group, $24(60 \%), 13$ (32.5\%) and 3 (7.5\%) patients were skilled, had some and had no skill on self-management of diabetes pre-intervention respectively. Post-intervention; $24(60 \%)$ patients were skilled, 11 (27.5\%) participants had some skill and 5 (7.5\%) participants had no skill.

In the experimental group, 38 participants were highly skilled representing $46.9 \%, 20$ participants were moderately skilled representing $24.7 \%$ while 23 respondents had low skill representing $28.4 \%$. The post-intervention scores revealed 57 respondents representing $70.4 \%$ had high skill while 23 respondents had moderate skill and 1 respondent had low skill representing $28.4 \%$ and $1.2 \%$ respectively.
The mean scores of the control group were 13.25 \pm 6.07 and $13.05 \pm 6.44$ pre and post-intervention and $8.12 \pm 7.06$ and $20.77 \pm 5.28$ pre- and post-intervention for the experimental group. The mean gains were -0.20 and 12.65 in the 2 groups respectively. The maximum score was 26 while the minimum score was 14 for post-intervention in the control group. Minimum scores pre- and post-intervention for the experimental group were 0 and 7 respectively, while maximum score pre- and post-intervention for the experimental group were 24 and 40 respectively. The score range for control group pre- and post-intervention were 13 and 12, and 24 and 33 for experimental group respectively.

Results from Table 4 shows 77 (95.1\%) and 81 (100.0\%) respondents had knowledge above average pre- and post-intervention respectively. Four (4.9\%) respondents had average knowledge pre-intervention. The mean score for pre-intervention was $61.32 \pm 6.99$ and $71.98 \pm 1.52$ for post-intervention. The mean gain is 10.66 . The maximum score was 73 for both pre- and post-intervention while the minimum scores were 42 and 66 post-intervention. The range score for pre- and post-intervention were 31 and 7 respectively.

Table 4: The difference in pre and post-intervention mean knowledge score of diabetic patients on self-management of diabetes in the experimental group.

\begin{tabular}{|c|c|c|c|c|c|}
\hline \multirow[b]{2}{*}{ Level of knowledge } & \multirow[t]{2}{*}{ Score range } & \multicolumn{2}{|c|}{$\begin{array}{l}\text { Pre Intervention } \\
(\mathrm{n}=\mathbf{8 1})\end{array}$} & \multicolumn{2}{|c|}{$\begin{array}{l}\text { Post Intervention } \\
(\mathrm{n}=\mathbf{8 1})\end{array}$} \\
\hline & & $\mathbf{F}$ & $\%$ & $\mathbf{F}$ & $\%$ \\
\hline Above average & $21-31$ & 77 & 95.1 & 81 & 100.0 \\
\hline Average & $11-20$ & 4 & 4.9 & 0 & 0.00 \\
\hline Below average & $0-10$ & 0 & 1.32 & 0 & 0.00 \\
\hline Total & & 81 & 100.0 & 81 & 100.0 \\
\hline Mean score & & \multicolumn{2}{|c|}{$26.04 \pm 2.97$} & \multicolumn{2}{|c|}{$30.57 \pm 0.64$} \\
\hline Mean gain & & \multicolumn{4}{|c|}{4.53} \\
\hline Maximum & & \multicolumn{2}{|l|}{31.00} & \multicolumn{2}{|l|}{31.00} \\
\hline Minimum & & \multicolumn{2}{|l|}{17.84} & \multicolumn{2}{|l|}{28.03} \\
\hline Range & & \multicolumn{2}{|l|}{13.16} & \multicolumn{2}{|l|}{2.97} \\
\hline
\end{tabular}

Table 5: The difference in pre and post-intervention mean skill score of diabetic patients on self-management of diabetes in the experimental group.

\begin{tabular}{|c|c|c|c|c|c|}
\hline \multirow[b]{2}{*}{ Level of skill } & \multirow[b]{2}{*}{ Score range } & \multicolumn{2}{|c|}{$\begin{array}{l}\text { Pre Intervention } \\
(\mathrm{n}=\mathbf{8 1})\end{array}$} & \multicolumn{2}{|c|}{$\begin{array}{l}\text { Post Intervention } \\
(n=81)\end{array}$} \\
\hline & & $F$ & $\%$ & $\mathbf{F}$ & $\%$ \\
\hline Skilled & $6-11$ & 38 & 46.9 & 57 & 70.4 \\
\hline Some skill & 5 & 20 & 24.7 & 23 & 28.4 \\
\hline No skill & $0-4$ & 23 & 28.4 & 1 & 1.2 \\
\hline Total & & 81 & 100.0 & 81 & 100.0 \\
\hline Mean score & & \multicolumn{2}{|c|}{$8.12 \pm 7.06$} & \multicolumn{2}{|c|}{$20.77 \pm 5.28$} \\
\hline Mean gain & & \multicolumn{4}{|c|}{12.65} \\
\hline Maximum & & \multicolumn{2}{|l|}{24} & \multicolumn{2}{|l|}{40} \\
\hline Minimum & & \multicolumn{2}{|l|}{0} & \multicolumn{2}{|l|}{7} \\
\hline Range & & \multicolumn{2}{|l|}{24} & \multicolumn{2}{|l|}{33} \\
\hline
\end{tabular}


Result from Table 5 shows that 38 (46.9\%) respondents were skilled on self-management of diabetes pre-intervention, while $57(70.4 \%)$ respondents were skilled post-intervention. Twenty (24.7\%) respondents had some skill pre-intervention and 23 (28.4\%) post-intervention. Twenty-three (28.4\%) had no skill pre-intervention and only $1(1.2 \%)$ post-intervention. The mean score for pre-intervention was $8.12 \pm 7.06$ and $20.77 \pm 5.28$ for post-intervention. The mean gain was 12.65. The maximum scores were 24 and 40 for pre- and post-intervention, and 0 and 7 for minimum score pre and post-intervention. The range values were 24 and 33 pre- and post-intervention respectively.

The result from the Table 6 above revealed that there was no significant difference in the pre- and post-intervention mean knowledge score of diabetic patients on self-management of diabetes in the control group with P-value of 0.19 at 0.05 level of significance. The table also compared pre- and post-intervention skill of self management of diabetic in the control group with P-value of 0.854 at 0.05 level of significance, hence there was significant difference in the pre- and post-intervention mean skill score of diabetic patients on self-management of diabetes in the control group.

From the Table 7 there was significant difference in the mean score of both the knowledge and skill of participants in the experimental group as revealed by P-value at 0.000 respectively at 0.05 level of significance, hence there was significant difference in the pre- and post-intervention mean knowledge score of diabetic patients on self-management of diabetes in the experimental group as well as there was significant difference in the pre- and post-intervention mean skill score of diabetic patients on self-management of diabetes in the experimental group.

\section{Discussions}

A total of 121 respondents from the control and experimental groups participated in the study. Socio-demographic data revealed that about half of the respondents in both control and experimental groups were about 60 years and above representing $45 \%$ and $69.1 \%$ respectively. This result was supported by a study conducted by Marques, et al. [16] which stated that the average age range of the population in their study falls within $60-88$ years. Similarly, another intervention study by Abiodun, Olaogun and Oladayo [17] also revealed that a higher proportion of the participants in the study were 65 years and above. On the contrary Olajide, et al. [18] reported that the majority of respondents were within the ages of 55 to 59 years.

Majority of the participants in the two groups were married with $90.0 \%$ and $80.2 \%$ in the control and experimental respectively. In consonance with this finding is the study from Olajide, et al. [18], where $75 \%$ of the respondents were married. In the same vein a study by Abiodun, Olaogun and Oladayo [17] showed that $67.7 \%$ and $60.1 \%$ were married in the control and experimental groups respectively.

The highest academic qualification of the participants was tertiary education; a little above half in the control group, and about one-third of the experimental (57.5\% and $34.6 \%$ respectively). This is similar to findings reported by Olajide, et al. [18] with $55 \%$ having higher educational qualification and Abiodun, Olaogun and Oladayo [17] with majority of the participants ha-

Table 6: T-test to Compare Mean Scores of Pre and Post intervention mean knowledge score and skill of patients on selfmanagement of diabetes in the control group.

\begin{tabular}{|c|c|c|c|c|c|c|c|c|c|}
\hline & Groups & $\mathbf{N}$ & Mean & Std. Dev & Std. Error Mean & t value & df & $\mathbf{P}$ & Remark \\
\hline $\begin{array}{l}\text { Knowledge on } \\
\text { self-management } \\
\text { of diabetes }\end{array}$ & $\begin{array}{l}\text { Pre Intervention } \\
\text { Post } \\
\text { Intervention }\end{array}$ & 40 & $\begin{array}{l}25.81 \\
25.50\end{array}$ & 2.58 & $\begin{array}{l}0.40 \\
0.39\end{array}$ & 1.325 & 39 & 0.19 & $\begin{array}{l}\text { Not } \\
\text { Significant }\end{array}$ \\
\hline $\begin{array}{l}\text { Skill on self- } \\
\text { management of } \\
\text { diabetes }\end{array}$ & $\begin{array}{l}\text { Pre Intervention } \\
\text { Post } \\
\text { Intervention }\end{array}$ & $\begin{array}{l}40 \\
40\end{array}$ & $\begin{array}{l}13.25 \\
13.05\end{array}$ & $\begin{array}{l}6.07 \\
6.44\end{array}$ & $\begin{array}{l}0.96 \\
1.01\end{array}$ & 0.186 & 39 & 0.854 & $\begin{array}{l}\text { Not } \\
\text { significant }\end{array}$ \\
\hline
\end{tabular}

Table 7: T-test to Compare Mean Scores of Pre and Post intervention mean knowledge score and skill of diabetic patients on self-management of diabetes in the experimental group.

\begin{tabular}{|l|l|l|l|l|l|l|l|l|l|}
\hline & Groups & N & Mean & $\begin{array}{l}\text { Std. } \\
\text { Dev }\end{array}$ & $\begin{array}{l}\text { Std. Error } \\
\text { Mean }\end{array}$ & t value & df & P & Remark \\
\hline $\begin{array}{l}\text { Knowledge on } \\
\text { self-management } \\
\text { of diabetes }\end{array}$ & Pre-Intervention & 81 & 26.04 & 2.97 & 0.33 & -13.72 & 80 & 0.000 & Significant \\
\hline $\begin{array}{l}\text { Skill on self- } \\
\text { management of } \\
\text { diabetes }\end{array}$ & Post-Intervention & 81 & 30.57 & 0.64 & 0.71 & & & & \\
& Pre-Intervention & 81 & 8.12 & 7.06 & 0.78457 & -17.01 & 80 & 0.000 & Significant \\
\hline
\end{tabular}


ving higher academic qualification with 11 (35.5\%) and $12(20.5 \%)$ in control and experimental groups respectively. Only minority of the participants do not have formal education.

About two-fifth of the participants were employed with $40 \%$ and $39.5 \%$ in the control and experimental groups respectively. However, Olajide, et al. [18], reported a different findings with majority $8(40 \%)$ of their respondents were neither civil servants nor traders.

Notably, majority of the participants had good knowledge on diabetic diet and this is supported by Sharma and Bhandari [19] where $86 \%$ had good knowledge of diabetic plan. This is also substantiated by Kushawa, Kumari and Kushwaha [20] stating that $75 \%$ of the patients had good knowledge of diabetic diet. In contrast, Selvaraj, Ramaswamy, Radhakrishnan, Thekkur, Chinnakali and Roy [21] discovered that despite that majority (99.4\%) received education on diet plan, only two-thirds of the respondents practiced it.

However, a larger percentage of the participants had poor knowledge of foot care. This is confirmed by Alshammari, Alsaid, Parameaswari, and Alzahrani [22] where $22.2 \%$ had knowledge of foot care. Similarly, a study conducted in India by Krishnan and Thirunavukkarasu [23] revealed that $75.8 \%$ had poor knowledge and did not practice self blood glucose monitoring in a proper way.

In addition, majority of the respondents had fairly good knowledge on self-management of diabetes both in the control and experimental groups pre-intervention. This differs from the findings reported by Abiodun, Olaogun and Oladayo [17] that at the pre-intervention phase, the control and experimental groups had poor knowledge of self-management. Also, at the post-intervention phase, there was knowledge gain among the experimental group, there was a significant difference in the pre and post-intervention mean knowledge score of patients on self-management of diabetes in the experimental group. This is corroborated by Farahat, Salama and Essa [24], who also reported significant difference post-intervention in the experimental with respect to intervention given. Similar studies by Olajide, et al. [18] and Abiodun, Olaogun and Oladayo [17] revealed that there was knowledge gain in the experimental group.

Less than half of experimental group and slightly above half in the control group, were skilled at the pre-intervention phase on self monitoring of blood glucose and foot care. This is in consonance with the interventional studies of Marques, et al. [16] and Abiodun, Olaogun and Oladayo [17] that participants had poor self-care practices. Farahat, Salama and Essa [24], study on foot care showed a high percentage of non-adherences to foot care parameters among respondents. Results from the pre and post intervention mean skill score in the control and experimental groups showed that there was skill gain among the experimental group as revealed by a score of -0.20 and 12.65 respectively. There was also a significant difference in the pre and post intervention mean skill score of patients on self-management of diabetes in the experimental group.

Moreover, some other studies that are not experimental were in agreement with the findings of low skill as reported by Krishnan and Thirunavukkarasu [23], where $75.8 \%$ of respondents had low skill in demonstrating self monitoring of blood glucose in a proper way. Similarly, Ajayi [25] stated that, only $17 \%$ of the respondents demonstrated self-monitoring of blood glucose. Regarding foot care, some studies revealed that respondents who had poor knowledge of foot care demonstrated poor practice of foot care as discovered by Desalu, et al. [14] and that only $10.2 \%$ of respondents had good practice of foot care. In the same vein Pourkazemi, Ghanbari and Khojamli, et al. [26] found out that $91.2 \%$ had poor practice of foot care. Similarly, another study carried out by Selvaraj, et al. [21] revealed only washing of feet were carried out by $83.3 \%$ of the respondent, all other foot care practices were less common.

\section{Limitations}

The major limitation of the study was the constraints posed on the sample size, especially in the control group due to the COVID-19 pandemic, although total enumeration of patients that attended the endocrine clinics of the two settings was utilized for the study during the time of sample collections. Hence, there was non-equivalence in the control and experimental group. Also, the study was a quasi-experimental which did not allow for randomization of the respondents.

\section{Conclusion}

The study concluded that nursing intervention on knowledge and skill is very vital in ensuring that patients are equipped to self-manage diabetes as it is one of the crucial and key components in the management and prevention of its' complications. This was demonstrated in the experimental group with improvements in knowledge and skill of self-management of diabetes among the participants post-intervention.

\section{Implication of the Study}

Self-management of diabetic patients could be achieved through effective nursing intervention. The availability of a well-designed educational package administered steps wisely to diabetic patients will foster standardized and effective knowledge based nursing intervention that will improve self-management among this population. This may also encourage further studies on factors that may enable effective nursing intervention on self management of diabetic patients.

\section{Acknowledgements}

There is no conflict of interest at all. We appreciate 
the efforts of all our research assistants and heads units of the study settings.

\section{Sources of Support}

No funding was received from any organization.

\section{Statement of Equal Authors' Contribution}

All the authors contributed to the research work up to this level.

\section{References}

1. Porth CM (2015) Essentials of pathophysiology: Concepts of altered health states. ( $4^{\text {th }}$ edn), Wolters Kluwer Philadephia, USA.

2. International Diabetes Federation (2017) IDF Diabetes Atlas. ( $8^{\text {th }}$ edn).

3. European Society of Cardiology (2019) Global statistics on diabetes.

4. World Health Organisation (2019) Diabetes programme.

5. Agofure O, Oyewole OE, Igumbor EO, Nwose EU (2018) Diabetes care in delta state of Nigeria: An Expository Review. Diabetes Updates 1: 1-8.

6. World Health Organisation (2016) Global report on diabetes.

7. Jackson IL, Adibe MO, Okonta MJ, Ukwe CV (2014) Knowledge of self-care among type 2 diabetes patients in two states of Nigeria. Pharm Pract 12: 404.

8. Essien O, Out A, Umoh V, Enang O, Hicks JP, et al. (2017) Intensive patient education improves glycaemic control in diabetes compared to conventional education: A randomised controlled trial in a Nigerian Tertiary Care Hospital. PLoS One 12: e0168835.

9. Powers MA, Bardsley J, Cypress M, Duker P, Funnell MM, et al. (2015) Diabetes self management education and support in type 2 diabetes: A joint position statement of the American Diabetes Association, the American Association of Diabetes Educators, and the Academy of Nutrition and Dietetics. Diabetes Care 38: 1372-1382.

10. Chali SW, Saleh MH, Abate AT (2018) Self-care practice and associated factors among diabetes mellitus patients on follow up in Benishangul Gumuz Regional State Public Hospitals, Western Ethiopia: A cross-sectional study. Bio Med Central Journal 11: 833.

11. Toobert DJ, Hampson SE, Glasgow RE (2019) The summary of diabetes self-care activities measure: Results from 7 studies and a revised scale. Diabetes Care.

12. Iregbu SC, Iregbu FU (2016) A review of self-management of diabetes in Africa. African Journal of Diabetes Medicine, 24.

13. Bonger SW, Shiferaw MH, Tariku AT (2018) Adherence to diabetic Self-care practices and its associated factors among patients with type 2 diabetes in Addis Ababa, Ethiopia. Patient Prefer Adherence 12: 963-970.
14. Desalu OO, Salawu FK, Jimoh AK, Adekoya AO, Busari OA, et al. (2011) Diabetic foot care: Self reported knowledge and practice among patients attending three tertiary hospital in Nigeria. Ghana Med J 45: 60-65.

15. Osuji NA, Ojo OS, Malomo SO, Ige AM, Egunjobi AO, et al. (2019) Glycaemic control and practice of self-care behaviors among people with type 2 diabetes in Nigeria. People Living with and Inspired by Diabetes Journal, 5 .

16. Marques MB, Coutinho JFV, Martins MC, Lopes MVO, Maia JC, et al. (2019) Educational intervention to promote self-care in older adults with diabetes mellitus. Rev Esc Enferm USP 53: e03517.

17. Abiodun OO, Olaogun AAE, Oladayo AAO (2020) Educational intervention impacts on knowledge and performance of self-care practices among type 2 diabetes mellitus patients in selected hospitals in Southwestern, Nigeria. International Journal of Diabetes and Clinical Research 7: 124.

18. Olajide TE, Nwaokocha C, Aina F, Ogunfowokan O, Awoniyi AM (2017) Effect of Nurse-led Training on Self-management of diabetes among diabetic patients attending medical outpatient clinic in general hospital Odan, Lagos State, Nigeria. Journal of Advances in Medicine and Medical Research 24: 1-8.

19. Sharma S, Bhandari SD (2014) Knowledge and practice regarding self-care among the patients with type II Diabetes of Kapan, Kathmandu. Journal of Advanced Academic Research, 1.

20. Kushawa AS, Kumari S, Kushwaha N (2015) Self-management in diabetes: A study amongst diabetics in an urban community. International Journal of Community Medicine and Public Health 3: 293-298.

21. Selvaraj K, Ramaswamy G, Radhakrishnan S, Thekkur P, Chinnakali $P$, et al. (2016) Self-care practices among diabetes patients registered in a chronic disease clinic in $\mathrm{Pu}$ ducherry, South India. J Soc Health Diabetes 4: 25-29.

22. Alshammari ZJ, Alsaid LA, Parameaswari PJ, Alzahrani AA (2019) Attitude and knowledge about foot care among diabetic patients in Riyadh, Saudi Arabia. J Family Med Prim Care 8: 2089-2094.

23. Krishnan V, Thirunavukkarasu J (2016) Assessment of knowledge of self blood glucose monitoring and extent of self titration of anti-diabetic drugs among diabetes mellitus patients - A cross sectional, community based study. J Clin Diagn Res 10: FC09-11.

24. Farahat TM, Salama AA, Essa LE (2016) Self-care knowledge among type 2 diabetic patients attending primary healthcare centers, Cairo governorate. Menoufia Medical Journal 29: 1060-1065.

25. Raimi TH, Adewuya OA, Ajayi AO (2015) Knowledge and practice of self monitoring of blood glucose. Research Journal of Health Sciences, 3.

26. Pourkazemi A, Ghanbari A, Khojamli M, Balo H, Hemmati $\mathrm{H}$, et al. (2020) Diabetic foot care: Knowledge and practice. BMC Endor Disord, 20. 


\section{Supplementary List}

\section{INSTRUMENT I}

\section{SECTION A: SOCIO DEMOGRAPHIC CHARACTERISTICS}

Instruction: Please tick or write as appropriate.

1. Age in years (i) 30-39 years[ ] (ii) 40-49 years [ ] (iii) 50-59 [ ] (iv) 60 years and above [ ]

2. Religion: (i) Christianity [ ] (ii) Islam [ ] (iii) Traditional [ ] (iv) Others [ ]

3. Marital status: (i) Single [ ] (ii) Married [ ] (iii) Divorced [ ] (iv) Separated [ ] (iv) Widowed [ ]

4. Ethnic group: (i) Yoruba [ ] (ii) Igbo [ ] (iii) Hausa [ ] (iv) Others (specify)

5. Level of education: (i) None (no formal education) [ ] (ii) Primary [ ] (iii) Secondary [ ] (iv) Tertiary [ ]

6. Occupation: (i) Employed [ ] (ii) Unemployed [ ] (iii) Retired [ ]

7. Duration of Illness years

\section{SECTION B: KNOWLEDGE ON SELF-MANAGEMENT OF DIABETES MELLITUS}

Instruction: Please tick or write as appropriate.

\begin{tabular}{|c|c|c|c|}
\hline $\mathbf{S} / \mathbf{N}$ & Items & True & False \\
\hline & Diabetes means that blood glucose is too high & & \\
\hline & Diabetes is a serious disease but it can be managed & & \\
\hline & The main types of diabetes are type 1 and type 2 & & \\
\hline & The usual cause of diabetes is lack of effective insulin in the body & & \\
\hline & $\begin{array}{l}\text { I AM the most important member of the health care team because I can help my } \\
\text { healthcare team to make a diabetic care plan that will work for me. }\end{array}$ & & \\
\hline & SMBG) enables me to monitor and react to changes in my blood glucose levels & & \\
\hline & It allows me to integrate my diabetes into the life style I want to live & & \\
\hline & $\begin{array}{l}\text { Self-monitoring of blood glucose involves checking of blood glucose yourself using a } \\
\text { glucometer }\end{array}$ & & \\
\hline & $\begin{array}{l}\text { Self-monitoring of blood glucose (SBGM) allows doctor and other healthcare team to } \\
\text { gather data for treatment planning }\end{array}$ & & \\
\hline & Fasting blood sugar is sugar level after at least four hours of no food intake & & \\
\hline & Fasting blood sugar enables me to know the overnight effect of medication & & \\
\hline & A person with diabetes fasting blood sugar value is above $126 \mathrm{mg} / \mathrm{dL}$ & & \\
\hline & Random blood sugar level is levels of glucose in the blood at any given point in the day & & \\
\hline & Random blood sugar level for a person with diabetes is more than $200 \mathrm{mg} / \mathrm{dL}$ & & \\
\hline & $\begin{array}{l}\text { Random blood sugar enables me to know if the way I am feeling is due to changes in } \\
\text { my blood sugar }\end{array}$ & & \\
\hline & \multicolumn{3}{|l|}{ Tick the appropriate range of blood glucose that is normal } \\
\hline & $70-110 \mathrm{mg} / \mathrm{dl}$ & & \\
\hline & $30-100 \mathrm{mg} / \mathrm{dl}$ & & \\
\hline & \multicolumn{3}{|l|}{ Tick the appropriate frequency of self- testing for blood sugar levels } \\
\hline & Anytime during the day & & \\
\hline & Twice a week & & \\
\hline & Once a month & & \\
\hline & Every clinic day & & \\
\hline & Diabetic diet is healthy-eating plan that will help in controlling of blood sugar & & \\
\hline & Tick the appropriate pattern a diabetic diet should follow & & \\
\hline & Breakfast, Lunch, Dinner & & \\
\hline & Breakfast, snack, lunch, Dinner & & \\
\hline & Breakfast, snack, lunch, Snack, dinner, snack & & \\
\hline
\end{tabular}


Tick the suitable content a diabetic meal should contain

Energy food $1 / 2$; Proteins $1 / 4$; Vegetables and fruit $1 / 4$

Energy food $1 / 4$; Proteins $1 / 4$; Vegetables and fruit $1 / 2$

Energy food $1 / 4$; Proteins $1 / 4$; Vegetables and fruit $1 / 4$

Physical exercise benefits the overall health status of DM patients

How often should a diabetic patient exercise?

Once per week

Twice per week

Thrice per week

Everyday

How long should each exercise session last?

Between 10 and 30 minutes

1-45 minutes

46-60 minutes

Above 1 hour

Diabetic patients do not need to inspect their feet daily

Diabetic patients should wash their feet daily

Lukewarm water should be used to wash the feet

After washing, feet should be dried immediately

35. Diabetic patients can get a pedicure to treat corn and calluses

36. A person with diabetes should take extra care when cutting his/her toenails

37. Tight shoes should be avoided

38. Shoes should be checked properly for dirt or pebbles before it is worn

39. If wearing socks, they should be firm/tight

\section{INSTRUMENT II}

Rating Scale for Evaluating the Skills of Diabetic Patients on Self Monitoring Of Blood Glucose (SMBG) and Foot Care

\begin{tabular}{|c|c|c|c|c|}
\hline $\mathbf{S} / \mathbf{N}$ & Selected Self-Management skills & 0 & 1 & 2 \\
\hline 1 & $\begin{array}{l}\text { Self Monitoring Of Blood Glucose (SMBG) } \\
\text { a. Wash your hands with soapy water and dry them well/ use sanitizer } \\
\text { b. Insert the test strip into the glucose meter. } \\
\text { c. Insert the lancet into the lancing device. } \\
\text { d. Prick the end of a finger (on the side). } \\
\text { e. Gently squeeze the end of your finger, if necessary. } \\
\text { f. Apply the blood to the test strip. } \\
\text { g. Wait a few seconds (the time varies by type of meter). } \\
\text { h. Read and write down the result in a logbook or store it in the glucose } \\
\text { meter. }\end{array}$ & & & \\
\hline 2 & $\begin{array}{l}\text { Foot Care after Bathing } \\
\text { a. Check the feet and toes, inspecting the tops, sides, soles, heels, and the } \\
\text { area in between the toes. } \\
\text { b. Inspect your feet for cuts, blisters, cracks, redness, swelling and nail } \\
\text { problems } \\
\text { c. Shake your shoes and feel the inside for pebbles } \\
\text { d. Choose comfortable, well-fitting shoes with plenty of room, especially in } \\
\text { the toe box. }\end{array}$ & & & \\
\hline
\end{tabular}

